\title{
A Choice between Dependence and Interdependence: The Baltic States in Quest for Peace and Prosperity
}

\author{
Viljar Veebel ${ }^{1}$ \\ ${ }^{1}$ Estonian National Defence College, Tartu, Estonia \\ Correspondence: Viljar Veebel, Estonian National Defence College, Riia 12-402, Tartu 51013, Estonia. E-mail: \\ viljar.veebel@gmail.com
}

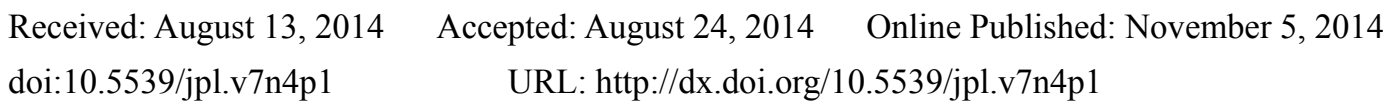

\begin{abstract}
Interdependence is a political and institutional tool, which can work either in favor of or against the needs of small member states in the international organisations. The European model of co-operation based on economic interdependence and integration has been the indisputable success for the last half of a century. At the same time, interdependence does not solely offer opportunities, but also entails risks. Theoretically, the weakness of the securitization based on the interdependence is related to the situation where some member states receive more gains from the interdependence than others, but feel less motivated to pay the costs associated to security. In this case, interdependence can also create security illusion and make some member states in the community be less careful and responsible both in terms of economic and military security. For small states the needs and threats are different than for bigger member states in the core. High economic openness and vulnerability to external shocks, dependence from the external capital flows leaves them less options for long-term stability. This study aims to analyse the relationship between the interdependence, security and welfare, discussing whether interdependence should be considered as a simple, linear mechanism which increases the security and welfare of all participants, or it also involves risks related both to economic and security aspects, which should be evaluated before applying for a membership in the international organisations. Are the security and prosperity gains expected from interdependence and integration real or rather an "illusion" what small states would like to believe in and big states are happy to promote?
\end{abstract}

Keywords: Baltic States, European integration, security

\section{Introduction}

Since the establishment of the NATO and the European Communities, for the small European nation states, cooperation, integration and interdependence have been associated with growing peace and prosperity, guaranteeing their national security and sustainability. Interdependence and some loss of national sovereignty as side effects have been seen as a small price to be paid for the benefits received. At the same time, the debate on the reasonable level of interdependence and a suitable integration form for small states is mainly taking place on a theoretical and academic level. On a political level, supporting interdependence has been seen as a centrepiece of being "good European" and "committed NATO member". Especially among policy makers, it has been argued that in the complex security situation of the $21^{\text {st }}$ century, a small state does not have an option for full sovereignty and, therefore, the interdependence as best practical solution gives them the opportunity to get a reasonable return for the partial loss of sovereignty.

In the light of the renewed security situation in the $21^{\text {st }}$ century the issues related to independence, integration, and interdependence definitely need to be continuously analysed. With regard to the Russian aggression against Georgia, as well as the outbreak of the global financial crisis, the year 2008 to some extent constituted the end of illusion, that the existing network of collective security could provide desired results in any foreseeable security scenario. The violent conflicts in Ukraine forced by Russia in 2014, have increased the need to revise the role of the international organisations and the regional cooperation forms, as well as the conceptual logic and models of independence in general.

This study aims to analyse the relationship between the interdependence, security and welfare, discussing whether interdependence should be considered as a simple, linear mechanism which increases the security and welfare of all participants, or it also involves risks related both to economic and security aspects, which should 
be evaluated before applying for a membership in international organisations. Are the security and prosperity gains expected from interdependence and integration real or rather an "illusion" what small states would like to believe in and big states are happy to promote? Is interdependence sustainable during the times of economic and political crises? Hereby, special attention will be given to the needs of small member states of the EU and NATO - like the Baltic States -that are newcomers in the "European family" and are located at the external borders. More precisely, with regard to the Baltics, it will also be asked, whether in 2003-2004 a real alternative to the trans-European (i.e. EU-integration) and transatlantic interdependence (i.e. membership in NATO) existed?

\section{Theoretical Logic and Pathways of Integration and Interdependence}

Historically, the motivation behind cooperation and mutual interdependence among countries has primarily been related to the avoidance of war and the enhancement of security rather than expecting economic gains. In theoretical debates the main focus has been on the question how sustainable security and stability are related to the level of interdependence and integration. The economic reasoning of integration, which has arrived in the spotlight later, has thus been seen as an additional "reward" of interdependence.

The logic that peace could be reached through interdependence has its roots already in Immanuel Kant's essay on Perpetual Peace: A Philosophical Sketch. Published in 1795, it discusses the principles of politics and proposes guidelines for lasting peace and cooperation between the states. In his argument, Kant draws parallels between individuals and nations, stipulating that "... Just as in the case of individual men, Reason would drive them to give up their savage lawless freedom, to accommodate themselves to public coercive laws, and thus to form an ever-growing State of Nations. But as the Nations, according to their ideas of international law, will not have such a positive rational system, and consequently reject in fact what is right in theory, it cannot be realised in this pure form. Hence, instead of the positive idea of a Universal Republic we shall have as result only the negative surrogate of a Federation of the States averting war, subsisting in an external union, and always extending itself over the world".

According to the Doyle's interpretation $(1983,213)$, as the liberal state is represented through a sovereign government, its sovereignty is not a subject to any external controls. Based on Kant's remark a conclusion could be drawn that although the only rational step to avoid war would be the formation of an international state, the willingness of the state to give up its will to act is rather questionable. And, as Kant himself admits, this development would not lead towards a global national state, but at a federation of states. Thus, "dependency" is replaced by "interdependency", as all the states have to a certain extent remain sovereign but still live in the cooperation and integration with each other.

The contemporary debate on interdependence and its correlation to peace and prosperity offers much food for thought as in a number of studies, interdependence and interstate cooperation are seen in a positive context. For example, contemporary interpretations of Kant speak about the Kantian tripod - either in form of a synergy between democracy, international law/organizations and economic interdependence (see, e.g. Russett, Oneal \& Davis 1998; Oneal \& Russett 2000 and Choi 2010).

The correlation between interdependence and integration has been in the centre of academic and political debates for decades. Most of the studies agree that international and intergovernmental organisation matter in certain context but the final outcome might differ, stemming from the fact that international organisations vary in their mandate, structure, etc., which also leads to the varying impact of international and intergovernmental organisation on interstate disputes (Boehmer, Gartzke \& Nordstrom 2004). However, the linkage between economic interdependence and peace is seen as one of the central questions to be studied in this context.

The traditional integration theorists (see e.g. the works of Jean Monnet, Robert Schuman, Ernst Haas, and Leon Lindberg) have stipulated that mutual interdependence is simultaneously seen as the pre-condition and driving force of integration process as well as its ultimate value, as it makes economic cooperation more effective by simultaneously making member states more dependent from each other in terms of security and motivating them to fight collectively for peace and stability in the region. For example, in a neo-functionalist model, which comprises the most comprehensive theoretical basis for European integration, economic interdependence is considered as a starting condition for explaining the motivation of the member states for long-term cooperation (see Risse 2005, 299). The integration process develops through three phases. The first phase sees a deepening of the transnational activities and economic interdependence, which also enhances further political integration between the member states. The second phase includes finding solutions to the commonly shared problems at the regional level, to gain collectively the benefits from deepening of transnational activities. The third phase covers the establishment of supranational organisations of governance to supply the rules for solving common problems in turn generating further interdependence (Sandholtz 2010, 7). 
But there are also problematic aspects related to interdependence as a part and parcel of integration. According to the neo-functionalist model, successful integration needs continuous progress in terms of deepening and widening of the integration. Thus, it could not be stopped at certain level, but must be continuously deepened and widened (the so-called "spill-over effect") to "survive and not to lose everything". In practical terms, this might lead to the situation where in certain situations the interdependence is definitely not the universal "win-win" game in terms of security and prosperity in every scenario, but some member states might become the victims of the "common need". This argumentation could also be related to the tendency that in practical matters - at the policy-making level - the debate on the risks related to interdependence as well as to the justified level of interdependence is rather modest. Thus growing interdependence and centralization, together with growing transfer of legitimacy to the supranational level means also an inevitable loss of national independence and sovereignty. The questions are only "when", "at what speed" and "under what conditions" it takes place. As states by one of core founders of modern integration theory, Ernst Haas: "The end result is a new political community, superimposed over the existing ones" (Haas 1958, 16). Hereby, from a small country perspective, the most rational approach appears to be to keep integration process developing, but simultaneously to keep its speed as slow as possible, thereby postponing the loss of national sovereignty as long away as possible.

The idea of interdependence - the arrangements whereby nation states are in situations and under the conditions they can control, cooperate with each other on matters of common interest - is rationally understandable also for realist thinkers. The existence of control which allows all participating states to decide the extent and nature of this cooperation means that national sovereignty is not directly undermined (Nugent 2006, 558).

To summarize the theoretical options: in terms of political as well as economic integration, countries have to make a choice between independence, dependence and interdependence. Especially in trade-related issues, the choice is in some cases more philosophical than practical - particularly for a small country - due to the lack of practical alternatives in a short-term perspective. As stipulated by Robert Mundell, "a large currency area is better cushion against shocks than a small currency area, just as a large lake can absorb the impact of a meteor better than a small pond" (Mundell 2001, 16). At the same time, as suggested by Crescenzi (2005), two states could enjoy high levels of trade without being interdependent, should there exist an appropriate market structure (i.e. 'the country is able to find goods, services and resources from other states') as well as asset specificity (i.e. 'country is able to alter its own means of production to easily adapt to the changing needs of different/new trading partners'). The impact of interdependence and integration differs also in a situation where a country is considered as a policy taker, and policy opponent or policy maker in confederation or federal union (such as the EU). As small or peripheral member states are often mainly policy takers or even policy opponents without the option to reject it (e.g. the EU climate agreement), economic interdependence could have a negative impact for them even during the integration process.

\section{Empirical Study: Interdependence, Welfare and Security through Baltic Perspective in the EU and NATO}

Economic and military security are interconnected in the same manner as peace and prosperity are related within social processes. Accordingly, simultaneous memberships both in the EU and in the NATO are designed and aimed to offer the member states additional security and welfare.

The process of European integration from the 1950s until today has undoubtedly been a success story in international cooperation, including - in its different stages - liberalisation of trade between member states, establishment of the single market, introduction of a single European currency, coordination of macroeconomic policies, and the centralisation of the decision-making process. Mutual interdependence and integration have provided better opportunities to exploit the comparative advantages of the member states and the effects of scale as well as contributed to the more efficient allocation of resources. It has also given a strong impetus to legal harmonisation and standardisation, and created a framework for common activities in different areas from environmental policy to the promotion of human rights. Despite some negative side-effects (i.e. more centralization, more standardization, more protectionism and more redistribution), it could be stated that European integration has generated prosperity and human welfare on an unprecedented scale in the region. This success can also be measured in relative terms as the majority of the EU member states are leading in main economic as well as human development scoreboards.

However, in 2014 - when setting out the vision of Europe for next decades - the prospects of further integration are not so unequivocal. As stressed by Herman Van Rompuy, President of the European Council, the economic and political interdependence, especially among the Eurozone countries, accelerated mainly by the introduction of the single currency, does not allow for continuing divergences within a monetary union (Van Rompuy 2012). 
He also calls governments for a „new awareness of co-responsibility, as each country is not only responsible for itself but also for the monetary union as a whole“. This call is immediately followed by a political rhetoric: „We carry a common project, even if the choices are made nationally. Forgetting this in our actions undermines the common good“.

Due to the growing interdependence the European integration has gradually reached an advanced stage, such that further integration demands from the member states relinquishing sovereignty to the largest extent ever until now - as the neo-functionalist integration model explains - to "survive and not to lose everything". According to Van Rompuy (2012), "what we are going through is not a "renationalisation of European politics", it is the "Europeanisation of national political life"". As a result, while producing more welfare and security, the integration as well as interdependence would inevitably lead to the dominance of the European dimension in national political life as well as to the (near) complete loss of national sovereignty. At the same time, the willingness of the state to give up its will to act is rather questionable. The existence of control which allows participants to decide the extent and nature of the cooperation would - in principle - motivate them to cooperate but also leave them a choice to cease the common initiatives which could endanger further integration.

In this context, one should also not forget the extensive relations and high interdependence between the EU and the US, both in economic and political terms, starting with extensive trade and financial activities and finishing with political initiatives. Following Cooper (2014), the interdependence between the EU and the US is likely to increase as a result of globalization and further enlargements of the EU, which potentially may lower trade and investments barriers even further. For example, as argued by Sbragia (2010), geo-economic competition between the EU and the US has been the main factor in developing the EU trade policy. Since national and regional policies can have extraterritorial impact and vice versa, potentially a situation could occur where national interests of some EU member states could be sacrificed in favour of transnational co-operation.

Another challenging tendency with regard to interdependence is related to its possible asymmetric nature, particularly, in the inner relations between the EU member states. More precisely, within the last ten years, Germany as well as the Netherlands and Austria have been implementing a neo-mercantilist trade policy, expanding their exports within the EU and the Eurozone and increasing the competitiveness compared to their partners (like Greece, Spain, Portugal, Romania, Bulgaria, Hungary, etc.), where trade deficit towards Germany and other stronger European economies has increased. It has even been argued (Lucarelli 2011 and Cesaratto 2010) that the German neo-mercantilism has caused the current economic recession in Europe, and that the causes of recent economic and political problems in the EU are related to capital accumulation and export surpluses, "a situation in which, as is the case in Germany, most of the external net balance, are realized within Europe itself" (Bellofiore \& Halevi 2011). In practical terms, during the period 2000-2010, Germany was the only economy among the EU member states that managed to increase their share in the world export as well as in the European Union's total export. Although prima facie the situation could rather be interpreted as unilateral dependency, in real terms we are still talking about interdependence, as it also involves risks for the countries with trade surplus.

A similar challenge - asymmetry in mutual interdependence relations - arises with regard to the actual efforts in building collective security in the framework of NATO. For some member states NATO is clearly a form of interdependence (France and Germany), whereas for some member states it represents a form of asymmetric dependence (the Baltic States). On the one hand, direct contributions of the members to the budget of NATO are following a principle of common funding and made in accordance with a specific formula based on relative gross national income of a country. But in practice $72 \%$ of the Alliance's defense expenditures are covered by the United States, whereas only $28 \%$ of the budget is covered by the partner countries from Europe (including the United Kingdom with $6.9 \%$, France with $4.9 \%$, Germany with $4.6 \%$ and Italy with $2.0 \%$ ) and Canada (1.8\%) (NATO funding 2014). At the same time, the European members of NATO are arguably more vulnerable to the growing instability and threats in the region - particularly in the Eastern Europe as well as in the Mediterranean and the Middle East - than the United States. On the other hand, for the alliance, the small countries' participation could be seen as an optimisation of resources, whereas for small countries the NATO membership is considered as the ultimate ratio, the mean of last resort. Also, in the case of a failure of the collective security network, the loss for small countries would be significantly bigger than the loss of security for big countries (e.g. the United States, the United Kingdom, or France). From a pragmatic angle, although every single member of NATO is useful, most of the small member states are replaceable in terms of resources provided by a country, and their absence is not a matter of survival for the alliance as a whole. At the same time, for small member states, who have built their security conception on the ideas of collective security the failure of the alliance would be irreparable. 
From the small state perspective, this provokes one to ask if the security gains expected from interdependence and integration are real or if they simply compose a vision in which small states would like to believe in and which big member states are happy to promote? In any case, the "dual crisis of security and trust" of the early twenty-first century has put national sovereignty back at the heart of the global political system (Bressand 2011, 62). Similarly to trade relations, the collective defence network could also be interpreted in the "game theory" framework where it could be more profitable for a single member state to prefer national interests instead of the common ones. So far, this kind of attitude has been more noticeable while analysing the behaviour of the members of G7 and G20. For example, the asymmetry in secure balance within the NATO could lead to similar risks related to the asymmetry in trade relations between Germany and other EU member states. Coming briefly back to the latter, according to Stiglitz (2012), if some countries increase their net export, some other countries must increase their net imports, which might lead to a situation where countries with persistent trade deficits might face difficulties to finance their deficit. In addition, high levels of net imports weaken aggregate demand which might lead to the fiscal deficits. In a like manner, the potential fragmentation among the interests of the member states would bear a significant threat to a common security based on interdependence, as we have seen in the case of the financial crisis in Greece or the French Mistral deal with Russia in the light of the military conflict in Ukraine in 2014.

In 2014 the pressure to revise the principles of the collective security network has both internal and external origins. Is interdependence as sustainable in years of crisis and pressure as it was in years of growth? It has been warned of "a dim, if not dismal future" for NATO if it continues to be divided "between those willing and able to pay the price and bear the burdens of alliance commitments, and those who enjoy the benefits of NATO membership /.../ but don't want to share the risks and the costs" (Robert Michael Gates, the former Defence Secretary of the US, 2011). An even more fundamental statement by the recent US Defence Secretary, Chuck Hagel (2013), states that "over-dependence on any one country for critical capabilities brings with it risks", which has been interpreted by the media that „one of these risks is that the U.S. will soon tell its allies, if you don't invest much in your defence, neither will we. The U.S. will "rebalance" its own shrinking defence dollars to allies and partners that share the security burden more equitably. Too many European leaders refuse to realize that this long-festering problem is having a dangerously corrosive effect on the Alliance". Also, it could be argued that the EU member states have often considered their own national interests as more important than those of Europe, leading to the growing fragmentation of EU foreign policy. This tendency has triggered a significant increase in criticism in external action discourse and led some authors even to claim that the EU foreign policy is on the verge of failure, especially in recent years.

To conclude, the future and success of the European and transatlantic integration, next to the ability to overcome external manipulations, depends from the attempts to subdue possible inner fragmentation.

\section{Debate: Integration, Interdependence and Dependence: Options and Effects for Small States}

Drawing on the above, peace and prosperity based on interdependence make a complicated option for small states, especially so for the new member states in a union or for small states located at the external border. The Baltic States, meeting all these conditions, hence face a challenging situation in terms of securitization, without attractive alternative options. Based on the example of the Baltic countries' accession to the EU as well as Estonia's, Latvia's and Lithuania's membership in the NATO since 2004, one could argue that the challenges related to the dependence/interdependence both in economic and political terms were partially underestimated. More precisely, in 2003-2004, in military terms the NATO partnership was mainly seen in the light of the post-modern security community where soft and indirect security aspects dominated over traditional security and defence questions. In this context, in 2004 both the growing integration and specialisation in the framework of NATO have rather been seen as the fastest way to converge with the transnational security network than a solution to hard security threats.

In 2014, in a renewed security situation which appears to be more complex and demanding with regard to the essence, effects and long-term sustainability of the interdependence inside transatlantic partnership, for the Baltic States soft security threats are combined with hard security threats. And this demands a combined institutional solution. At the same time, despite the wishful thinking in the Baltic countries over the matters of security, the collective security network provided by the NATO offers for them dependence rather than mutual interdependence and in the case of a failure of collective security the loss for Baltic countries would be devastating. This dependency is also reflected by the fact that in terms of military power, according to the "Global Firepower" scoreboard in 2014, Estonia ranked on $96^{\text {th }}$ position and Lithuania on $103^{\text {rd }}$ position (Latvia not listed), whereas, for example, the UK was positioned as $5^{\text {th }}$, France as $6^{\text {th }}$ and Germany as $7^{\text {th. }}$. Thus, the Baltic countries appear to depend on the motivation and ability of the organisation - and its main contributor, the 
United States - to find solutions to the currently occurred hard security threats as well as to the risks related to the growing differences between the member states with regard to financial issues.

Also, a potential threat arises that in the interdependent union, small - or new - member states are forced to support as well as to finance joint policy initiatives which are driven by more influential members stipulating that the initiatives are useful for the alliance as a whole, but does not so much follow the interests of the small countries, or are, in some cases, even harmful for the small countries, as they take away resources from their specific needs. Support to the independence of Kosovo and participation in the Central African Republic mission from the view point of the Baltic countries could be discussed as probable examples. The same threat occurs with regard to the economic integration.

In military terms, the increasing competition as well as a possible fragmentation among the EU member states with regard to external powers will bear a significant threat to the common security network. More than $50 \%$ of the non-US defense expenditures are covered by the United Kingdom, France and Germany, and their defense spending - similarly to those of the US - will continue to be under pressure in a foreseeable future (NATO funding 2014).

In terms of actual efforts of Estonia, Latvia and Lithuania in building their security, the differences could be observed also between them. As agreed in 2006, NATO partner countries committed to spend a minimum of two percent of their GDP to defence budget. This could be seen to serve as an indicator of a country's political will to contribute to common defence efforts (NATO funding 2014). Whereas Estonia appears here as relatively strongly committed to the $2 \%$ obligation, both Latvia and Lithuania spend less than $1 \%$ of their GDP to military expenses. A majority of it has so far gone to cover the "solidarity costs", i.e. for military missions in Iraq, Afghanistan, etc., with the probable aim to gain something in return in the case of Russian pressure. Yet, while the transatlantic security cooperation and the dependence on the collective defense network are, in principle, supported in all of the Baltic countries, regional cooperation is considered much less attractive. This attitude could also be linked to the fact that the Baltic States are more eager to consume joint security than they could themselves actually offer. Accordingly, in military terms the Baltic countries could also be described as being "over-dependent" on some of the member states of the EU.

Nevertheless, since 2014 NATO has clearly recognized the threats arising from the Russian recent military moves in Eastern Europe and started to develop long term sustainable strategies to defend its Baltic members. Till this time, opinions have been expressed that NATO has been relatively unprepared in terms of military response if Russia would move into the Baltic countries (Spiegel 2014). This has been stressed by the Polish Foreign Minister Radoslaw Sikorski according to whom "there are bases in Great Britain, Spain, Germany, Italy and Turkey. But there aren't any bases where they are actually needed" (Ibid.). Although for many decades, specific NATO initiatives and missions have been prioritised over the local needs to provide higher level of summarized security and defence in the alliance, in recent years - after the Russian-Georgian war in 2008 as well as following the decision made by France to sell Mistral helicopter carriers to Russia disregarding the Russian-Ukraine military conflict in 2014 - some member states have also sensed the weakness of the existing model. There has arisen awareness that resources invested to guarantee joint security in the region might eventually not be used, because of the political considerations of some member states of the alliance.

Nonetheless, though some definitive risks arise from the size of the Baltic countries which hinders them of being equal partners in interdependent relationship to the US, Germany, the UK, etc., the historical legacy of the Baltic States has taught that also military (and economic) independence was not a solution for survival. Hence, despite its problems discussed above, a dependency on the collective security network will with all probability be considered as an optimal choice for them.

But the asymmetric tendencies can also be witnessed outside security matters, in economic terms, the asymmetric dependence of the Baltic States from the EU is rapidly growing. After regaining their independence in 1991, all the efforts were aimed at deeper integration with the EU. Estonia has, in general, managed to best exploit the advantages of the European Union's economic integration, especially in respect of the countries outside the EU. At the same time, in trade relations between Estonia and the EU the balance has been strongly in the European Union's favour. Estonia's largest trade deficit occurs in its trade with Germany, showing some signs of reduction of the deficit during the years of economic recession, but rapidly increasing again from 2010.

During the last ten years Estonian external trade with the other EU member states has annually increased on average by $9.5 \%$ and with third countries outside the EU by $9.7 \%$, in comparison to the EU-28 external trade annual growth rates which were, respectively, $3.5 \%$ and $6.3 \%$. Even despite the temporary setback in 2009 
induced by the economic crisis, the Estonian exports to countries outside the EU has shown a high growth of numbers (annual average growth rate 16.4\%).

A second complicating aspect is the growing fiscal dependence of the Baltic States from the EU central budget: in $2014,22 \%$ of the budget revenues in Estonia were directly or indirectly connected to the EU subsidies or supportive measures (Varblane 2014). The positive effect of receiving growing subsidies from the EU is that the Baltic States are able to sustain higher defense cost in the longer term. The downside of this interdependence is that on the one hand it puts additional costs to other member states and on the other hand the national economy will find itself in a very complicated situation should the central subsidies decrease (as was evident in the Greek case in recent years).

For the small member states of the European and transatlantic unions, especially in a stage of social and economic transition, the threats and needs are different from the bigger member states comprising the core area of integration. Accordingly, small countries naturally tend to implement additional tools for guaranteeing their security and stability. European integration and the economic interdependence from the EU look from that perspective as an almost ideal option for the Baltic States. But as was shown by the Eurozone financial crisis, the actual result may not be as successful as expected since due to the economic openness and country's dependence from external capital flows, the Baltic States - similarly to the other "peripheral" small countries like Ireland, Portugal, Greece and Cyprus - were more severely hit by the economic crisis. But one should also notice that, in contrast to other countries, the flexibility of the economies of the Baltic States have also contributed to their fast recovery from the crisis. Perhaps somewhat controversially, although high interdependence has not saved the Baltic countries from the crisis, but rather accelerated it, at least Estonia among them is still eager to build new forms of interdependence (e.g. the ESM and the EFSF) by stressing that these are the best options against potential threats in the future.

\section{Conclusions}

Interdependence is a political and institutional tool which can work either in favor of or against the needs of the small member states. The European model with economic interdependence and integration has been an undisputable success during last half a century: Europe has been peaceful since the introduction of the communities and the EU member states form the leading group in all major economic and human development scoreboards, showing the wellbeing and prosperity interdependence has brought. Compared to the economic integration, the transatlantic interdependence has often been seen as even a more secure and comfortable choice for small state policy makers to show that they made their best effort in term of national security and sustainability.

At the same time, interdependence do not solely offers opportunities, but also entails risks. Theoretically, the weakness of the securitization based on the interdependence is related to the situation where some member states receive more gains from interdependence than others, but feel less motivated to pay the associated costs. In this case, interdependence can also create security illusion and make member states be less careful and responsible both in terms of economic and military security. The global economic crisis since the year 2007 and the military conflicts around the borders of the EU have made this topic particularly intriguing for the relatively young and small EU and NATO member states located at the external borders explicitly facing hard security threats.

For small states the needs and threats are different than for bigger member states in the core. High economic openness and vulnerability to external shocks, dependence from external capital flows leaves them less options for long-term stability. After regaining independence in the beginning of the 1990s, the principle choice for the Baltic countries has been between supranationalism and sovereignty. Estonia, Latvia and Lithuania have chosen for maximum program to joining first the EU and NATO and accessing Schengen visa room and Eurozone as soon as possible.

In 2014, from the economic perspective the Baltic States are facing the dilemma whether to continue structural integration within the $\mathrm{EU}$ or to focus on international competitiveness, economic independence, and the efficient usage of country-specific resources. The first option would offer the Baltic countries more political support from the European partners as well as financial contributions from the structural funds, but would potentially motivate national economies to tend towards centralization and subsidies. The second option would offer national economies better opportunities in terms of market economy conditions, where country-specific advantages will be used for specialization and gaining international competitiveness. At the same time, as due to the growing interdependence the European integration has reached an advanced stage, where further integration is needed "not to lose everything", the second alternative is rather theoretical. Despite the fact that the dependence of the Baltic countries on the EU and NATO is quite obviously asymmetrical and further deepening of the integration 
would bring additional security risks, in real terms there exist no feasible alternatives for security and prosperity. To have interdependence instead of dependence, it also needs similarity in size and scope of the economies - the Baltic States can only be heavily dependent from the EU finances, while for the EU and other member states the Baltic impact is still marginal.

Considering the dynamic nature of integration and interdependence, the Baltic countries should probably count on even further loss of sovereignty, as a price to be paid for the benefits to be received. From their perspective, the potentially worst outcome would be a situation where small countries need to support and finance the policy initiatives which are not in their favour, that would take away their vital resources and, finally, even harming their economic competitiveness and security (as does, e.g. the standardization of energy policy or taxation).

At the same time, one could also follow the statement by Alan Milward who finds that "integration has always been a political choice rather than an inexorable consequence of growing "interdependence" or some of other functional factors" (Milward 2000). Thus, also further potential steps on the road of integration are inevitably leading to some loss of sovereignty and hence could be interpreted as matters of political choice, what countries have to make at the European level.

\section{References}

Bellofiore, R., \& Halevi, J. (2011, Winter). Could Be Raining. The European Crisis after the Great Recession. International Journal of Political Economy, 39(4), 5-30. http://dx.doi.org/10.2753/IJP0891-1916390401

Boehmer, C., Gartzke, E., \& Nordstrom, T. (2004). Do Intergovernmental Organizations Promote Peace? World Politics, 51(1), 1-38. http://dx.doi.org/10.1353/wp.2005.0008

Bressand, A. (2011). Between Kant and Machiavelli: EU Foreign Policy Priorities in the 2010s. International Affairs, 87(1), 59-85. http://dx.doi.org/10.1111/j.1468-2346.2011.00960.x

Cesaratto, S. (2010). Europe, German Mercantilism and the Current Crisis. Paper provided by Department of Economics, University of Siena, No. 595 (May). Retrieved from http://www.econ-pol.unisi.it/quaderni/595.pdf

Choi, S.-W. (2010). Beyond Kantian Liberalism: Peace through Globalization. Conflict Management and Peace Science, 27(3), 272-295. http://dx.doi.org/10.1177/0738894210366513

Cooper, W. H. (2014). EU-U.S. Economic Ties: Framework, Scope, and Magnitude. Congressional Research Service (Report), February 21, 2014. Retrieved from http://fas.org/sgp/crs/row/RL30608.pdf

Crescenzi, M. (2005). Economic Interdependence and Conflict in World Politics. Lanham, MD: Lexington Books.

Doyle, M. W. (1983, Summer). Kant, Liberal Legacies, and Foreign Affairs. Philosophy and Public Affairs, $12(3), 205-235$.

Flassbeck, H. (2012). German Mercantilism and the Failure of the Eurozone. Retrieved from http://yanisvaroufakis.eu/2012/04/21/german-mercantilism-and-the-failure-of-the-eurozone-guest-post-by-h einer-flassbeck/

Franzese, R. J. (Jr.), \& Hays, J. C. (2008). Interdependence in Comparative Politics: Substance, Theory, Empirics, Substance. Comparative Political Studies, 40th Anniversary Issue: Frontiers of Comparative Politics. March/April. Retrieved from http://www-personal.umich.edu/ franzese/FranzeseHays.CPS. InterdependenceCP.pdf

Gates, R. M. (2011). The Security and Defense Agenda (Future of NATO), (Speech delivered by Secretary of Defense Robert M. Gates in Brussels, Belgium, June 10, 2011. Retrieved from http://www.defense.gov/speeches/speech.aspx?speechid=1581

Gilpin, R. (1981). War and Change in International Politics. Cambridge University Press. http://dx.doi.org/10.1017/CBO9780511664267

Haas, E. (1958). The Uniting of Europe: Political, Social, and Economic Forces, 1950-1957. Stanford University Press.

Hagel, C. (2013). Will the U.S. "Rebalance" Its Contribution to NATO? Retrieved from http://www.defenseone.com/ideas/2013/10/will-us-rebalance-its-contribution-nato/72281/

Lucarelli, B. (2010, Winter). German neo-mercantilism and the European sovereign debt crisis. Journal of Post Keynesian Economics, 34(2), 205-224. http://dx.doi.org/10.2753/PKE0160-3477340202 
Milward. (2000). The European Rescue of the Nation-State (2nd ed.). Routledge.

Mundell, R. (2001). International Money as a Public Good: The Case for a World Currency. In Public Goods for Economic Development (Compendium of Background Papers). The United Nations Industrial Development Organization, pp. 5-30.

NATO funding. (2014). Retrieved from http://www.nato.int/cps/en/natolive/topics_67655.htm

Nugent, N. (2006). Government and Politics of the European Union. Basingstoke, Palgrave Macmillan.

Oneal, J. R., \& Russett, B. (2000). Triangular Peace: Democracy, Interdependence, and International Organizations. The Norton Series in World Politics.

Risse, T. (2005). Neofunctionalism, European Identity, and the Puzzles of European Integration. Journal of European Public Policy, 12(2), 291-309. http://dx.doi.org/10.1080/13501760500044033

Russett, B., Oneal, J. R., \& Davis, D. R. (1998). The Third Leg of the Kantian Tripod for Peace: International Oranizations and Militarized Disputes, 1950-85. International Organization, 52(3), 441-467. http://dx.doi.org/10.1162/002081898550626

Sandholtz, W., \& Stone Sweet, A. (2010). Neo-functionalism and supranational governance. The Oxford Handbook of the European Union.

Sbragia, A. (2010). The EU, the US, and Trade Policy: Competitive Interdependence in the Management of Globalization. Article presented at the European Union Studies Association $11^{\text {th }}$ Biennial Conference, California, 23-25 April 2009. Retrieved from http://aei.pitt.edu/33126

Spiegel. (2014). NATO unprepared if Russia moved into Baltic members. Retrieved from http://www.dw.de/spiegel-nato-unprepared-if-russia-moved-into-baltic-members/a-17643795

Stiglitz, J. E. (2012). In mercantilism doomed to fail? China, Germany, and Japan and the Exhaustion of Debtor Countries. Presentation of April 13, 2012. Retrieved from http://ineteconomics.org/sites/inet.civicactions.net/files/Stiglitz\%20Presentation.pdf

Streeten, P. (2001, June). Integration, Interdependence, and Globalization. Finance \& Development, 38(2).

Van Rompuy, H. (2012). The discovery of co-responsibility: Europe in the debt crisis (Speech at the Humboldt University, Walter Hallstein Institute for European Constitutional Law), 6 February 2012. Retrieved from http://www.consilium.europa.eu/uedocs/cms_data/docs/pressdata/en/ec/127849.pdf

Varblane, U. (2014). The Beauty and Pain of European Money. The Journal of Estonian Parliament, 25-39.

Veebel, V., \& Kasekamp, A. (2007). Overcoming Doubts: The Baltic States and European Security and Defence Policy. The Estonian Foreign Policy Yearbook, edited by Andres Kasekamp, Varrak.

\section{Copyrights}

Copyright for this article is retained by the author(s), with first publication rights granted to the journal.

This is an open-access article distributed under the terms and conditions of the Creative Commons Attribution license (http://creativecommons.org/licenses/by/3.0/). 